\title{
“Strange Bedfellows”: Gandhi and Chinese passive resistance 1906-11
}

\author{
Karen L. Harris \\ Department of Historical and Heritage Studies, University of Pretoria \\ Email: karen.harris@up.ac.za
}

\begin{abstract}
Over a century since Gandhi's historic and personally decisive sojourn in colonial southern Africa, the vast corpus of literature in the Western world on the Mahatma has continued to expand unabated, while the "machines of Gandhi hagiography" are still said to "continue to churn out massive volumes in present-day India". ${ }^{2}$ Indeed, this commemorative issue of the Journal of Natal and Zulu History is testimony to this legacy and ongoing fascination, and in particular commemorates a centenary of his global bequest of satyagraha (passive resistance) launched in southern Africa. While much of the literature produced on Gandhi continues to adhere to what Dilip Menon has called the "straight and narrow" ${ }^{3}$ or what Tanika Sarkar refers to as "icon making" ", with a persistent veneration of the Mahatma, others have ventured to question, probe, reappraise and reassess a range of dimensions of the Gandhian epoch. ${ }^{5}$ One aspect that has increasingly come under scrutiny is Gandhi's relations with other non-Indian communities, particularly as regards his time in South Africa and the emergence of satyagraha. ${ }^{6}$ This ties in with a wider concern about the possible contradictions in his professed rejection of racism and his claim to universalism. It is in this context that his apparent failure to ally with any other ethnic grouping within South Africa is questioned. ${ }^{7}$ And it is to this aspect of the satyagraha movement that this article turns, with particular reference to Chinese resistance at the turn of the century.
\end{abstract}

For some commentators, such as James Hunt, Gandhi's relationship with non-Indians in South Africa was, to say the least, "unsatisfactory". ${ }^{8}$ Some works are in fact extremely critical of his attitude, suggesting that the passive resistance campaign suffered as a result of its limited contact. For example, Paul Power goes as far as claiming that Gandhi actually facilitated the implementation of “divisive segregationist policies" and perpetuated "racialism” and even "proto-apartheid”. ${ }^{9}$ Moreover, Gandhi's role as a key political figure within the South African Indian community is questioned by authors such as Maureen Swan, as is his political leadership role in the broader multi-cultural South African context. ${ }^{10}$

\footnotetext{
${ }^{1}$ This article is a reworked version of a chapter entitled "Gandhi, the Chinese and Passive Resistance", in Gandhi and South Africa: Principles and Politics ed. Judith Brown and Martin Prozesky (Pietrmaritzburg: University of Natal Press, 1996), 69-95.

2 Arjun Appadurai, “Our Gandhi. Our times” Public Culture 23, no. 2, 2011, 264.

${ }^{3}$ Dilip Menon, “Gandhi was a Terrible Father and Husband”, Historia 57, no. 2, 2012, 500-1.

4 Tanika Sarkar, "Gandhi and Social Relations" in The Cambridge Companion, ed. Judith Brown and Anthony Parel (Cambridge: Cambridge University Press, 2011), 173.

${ }^{5}$ See for example, Claude Markovits, The UnGandhian Gandhi: The Life and Afterlife of the Mahatma

(London: Anthem Press, 2004); Jad Adams, Gandhi: Naked Ambition (London: Quercus, 2010).

${ }^{6}$ Surendra Bhana, "Gandhi” review of Burnett Britton, Gandhi Arrives in South Africa (Canton: ME Greenleaf books, 1999) in Journal of African History 42, no. 2, 2001, 329-30.

7 James D. Hunt, Gandhi and the Black People in South Africa, Gandhi Marq, April-June 1989, 7-8; Les Switzer, Gandhi in South Africa: The Ambiguities of Satyagraha, Journal of Ethnic Studies 14, no. 1, 1986; J. H. Stone II, Debate: M.K Gandhi: Some Experiments with Truth, Journal of Southern African Studies 16, no. 4, 1990, 726; Maureen Swan, Gandhi: The South African Experience (Johannesburg: Ravan Press, 1985), 113, 137.

${ }^{8}$ Hunt, Gandhi and the Black People, 7-8 refers to work by D.B Marthur, G. Ashe and L. Switser.

${ }^{9}$ Paul Power, "Gandhi in South Africa” Journal of Modern African Studies 7, no. 3, 1969, 445-6; M Tayal,

"Gandhi: The South African Experience” (Ph. D. diss., Oxford University, 1980).

${ }^{10}$ Stone II, Debate: M.K Gandhi, 722-6; Swan, Gandhi, 270-1; Bhana, “Gandhi”, 329-30.
} 
More recently, in a reappraisal of Gandhi's South African years, Surendra Bhana and Goolam Vahed have also paid some attention to the relationship between Gandhi and black South Africans. They argue that Gandhi paid little attention to Africans and their leaders, claiming that the "possibility of Gandhi's moulding a united front with other Black groups was never a realistic one ... given the circumstances around which Indianness came into being." 11 They admit to Gandhi's “ethnocentrism”, but appear to ratify the lack of non-Indian relations by emphasising his promotion of "Indianness" as the "best way to make the case for Indian rights". ${ }^{12}$ This is done against the background of the very different ways in which Indians and Africans were treated in the South African colonies in the nineteenth and early twentieth century. In a similar vein in another recent work, Claude Markovits points out that Gandhi "succeeded in earning respect, even friendship, of a few white men and women", pointing to the fact that he also had a "European secretary [Miss Schlesin] in his legal practice at Johannesburg". ${ }^{13}$ His relationship with Indians and whites is repeated on the very next page when Gandhi is described as having "showed an ability to form lasting friendships beyond racial barriers, with Indians and Europeans". ${ }^{14}$ He then adds - in telling parenthesis - that it "has been remarked, however, that in South Africa he [Gandhi] had no African friends". ${ }^{15}$ There again appears to be an attempt to contextualise this situation, as Markovits states earlier in the work that "Gandhi also earned a measure of respect from his European colleagues which, in as profoundly racist a society as colonial South Africa in the late nineteenth century was, was no mean achievement". ${ }^{16}$ It therefore becomes apparent that in numerous studies Gandhi is presented as having had relations with only certain select sectors of the South African Indian community in South Africa along with a few relationships with whites, and the lack of relations beyond this is either criticised or defended.

In the light of these trends in Gandhian historiography, an analysis of the involvement of the South African Chinese community in the passive resistance movement presents a different perspective on Gandhi's so-called "political exclusionism”, “ethnocentrism” and "illusiveness". However, the Chinese passive resistance movement is a fairly unknown event and has received relatively little attention by most Gandhian scholars and other historians, barring a few passing references or trivialising comments. For example, in the work by Power, Chinese participation in the passive resistance movement earns a mere sentence, which is both in parenthesis and inaccurate. ${ }^{17}$ James Hunt also dismisses the Chinese passive resistance as an alliance of "mutual self-interest", ${ }^{18}$ while G. Ashe refers to the Chinese resistance in passing as "joint action with a few Chinese". ${ }^{19}$ This view is perpetuated in Maureen Swan's renowned re-interpretive study, Gandhi: the South African Experience, in which the Chinese barely feature, and their role is reduced simply to making "good strategic

\footnotetext{
${ }^{11}$ Surendra Bhana and Goolam Vahed, The Making of a Political Reformer: Gandhi in South Africa, 1893-1914 (New Delhi: Manohar, 2005), 43.

${ }^{12}$ Bhana and Vahed, The Making of a Political reformer, 151.

${ }^{13}$ Markovits, The UnGandhian Gandhi, 80.

${ }^{14}$ Markovits, The UnGandhian Gandhi, 80-1.

${ }^{15}$ Markovits, The UnGandhian Gandhi, 81.

${ }^{16}$ Markovits, The UnGandhian Gandhi, 79.

${ }^{17}$ Power, Gandhi in South Africa. 450.

${ }^{18}$ Hunt, "Gandhi”, 11-12.

${ }^{19} \mathrm{G}$. Ashe quoted in Hunt, Gandhi and the Black People, 7-8.
} 
sense". ${ }^{20}$ She dismisses the Chinese passive resistance as a "parallel movement" which "need play no major part in a discussion of Indian passive resistance". ${ }^{21}$ While some recent work refers to the Chinese as being "subjected to the same laws as the Indians", ${ }^{22}$ others make no mention of the Chinese at all. ${ }^{23}$

Turning to the limited number of histories of the small Chinese community in South Africa, there are a few general monographs on the overseas Chinese by international scholars that include brief references to the passive resistance movement in South Africa. Once again, the relationship between the Chinese and Gandhi is not adequately addressed, but where it is, it is invariably portrayed as one in which Gandhi played a prominent leadership role. ${ }^{24}$ As early as the mid-1950s, Huang Tsen-ming indicates that "both Indians and Chinese resolved as a body not to register", but he qualifies this by stating categorically that the passive resistance movement had been "initiated under M.K. Gandhi". ${ }^{25}$ In her comprehensive global study of Chinese overseas, Lynn Pan also ascribes the defiance by the Indian and Chinese as having been led by "a young Indian lawyer, Mahatma Gandhi”. She does, however, concede that an "alliance was formed between the Indian and Chinese communities", indicating that "Gandhi worked closely with the chairman of the Cantonese Association". ${ }^{26}$ The work of Huguette Ly-Tio-Fane Pineo is one of the first to deviate slightly from this generalisation of a Gandhidominated Indian and Chinese collaboration. In her work on the China diaspora in the Western Indian Ocean, a more detailed account emerges where she attributes certain initiatives to the Chinese, but still depicts them as faithful "collaborators" with Gandhi and the Indians, where they "unite[d] their efforts" in their "struggle for civic rights". ${ }^{27}$ Although her account, which runs into several pages, includes one or two historical inaccuracies, it remains one of the first to present the Chinese as active participants in the resistance movement and also makes use of numerous primary sources, including Indian Opinion. ${ }^{28}$

In 1993, the University of Natal hosted a conference to commemorate the centenary of Gandhi's "transforming experience in Pietermaritzburg", and it was here that I first presented a paper on the Chinese and passive resistance. ${ }^{29}$ This was later published in 1996 in an edited volume by Judith Brown and Martin Prozesky, and forms the core on which the current

\footnotetext{
${ }^{20}$ Swan, Gandhi, 137-8.

${ }^{21}$ Swan, Gandhi, 143, 148-9, 171, 177.

${ }^{22}$ Keith Breckenridge, Gandhi’s Progressive Disillusionment: Thumbs, Fingers, and the Rejection of Scientific Modernism in Hind Sawaj, Public Culture 3 no. 2, 332 and 339. Although not the focus of this insightful article, the discord that arises between Gandhi and the Chinese specifically over the fingerprint issue would have made for an interesting discussion.

${ }^{23}$ Markovits, The UnGandhian Gandhi; D. Hardiman, Gandhi in His Time and Ours: The Global Legacy of His Ideas (Pietermaritzburg: University of Natal Press, 2003).

${ }^{24}$ Huang Tsen-ming, The Legal Status of the Chinese Abroad (Taipei: Chinese Cultural Service, 1954), 49-52; Lynn Pan, Sons of the Yellow Emperor: The Story of the Overseas Chinese (London: Mandarin Paperbacks, 1990), 66-7; Huguette Ly-Tio-Fane Pineo, Chinese Diaspora in Western Indian Ocean (Mauritius: MSM, 1985), 228-39 for the most comprehensive account.

${ }^{25}$ Huang, The Legal Status, 50-51.

${ }^{26}$ Pan, Sons of the Yellow Emperor, 66.

${ }^{27}$ Ly-Tio-Fane Pineo, Chinese Diaspora, 215, 228, 230, 227.

${ }^{28}$ Ly-Tio-Fane Pineo, Chinese Diaspora, 238-41.

${ }^{29}$ Karen Harris, "Gandhi, the Chinese and Passive Resistance”, International Conference on Gandhi and his Significance: Centenary Celebrations”, University of Natal, Pietermaritzburg, 1993.
} 
article is based. ${ }^{30}$ The Chinese passive resistance also formed a substantial part of a chapter in my doctoral dissertation, which was on the Chinese in the Transvaal at the turn of the twentieth century. ${ }^{31}$ In the splendidly-illustrated and -researched community history of the Chinese in South Africa by Melanie Yap and Dianne Man, Colour, Confusion and Concessions, this episode in the history of the South African Chinese also received extensive attention. $^{32}$ The chapter dedicated to Chinese passive resistance presents a detailed discussion of the event, highlighting the Chinese participation and focusing "primarily on the attitudes and activities of the Chinese". ${ }^{33}$ However, although this is indeed a very insightful account of the period of Chinese passive resistance, and one that the authors describe as the "most turbulent times in the history of the community", it surprisingly still adheres very much to the conventional perception that the Chinese "rallied behind Mahatma Gandhi's campaign” alongside the Indians. ${ }^{34}$

Despite this more recent research, which acknowledges the Chinese passive resistance within the broader context of South African historiography, and in particular that of Gandhi and satyagraha, the Chinese involvement in the period 1906-1911 remains fairly unknown. This historical narrative is crucial, given that the Chinese were the only non-Indian group to participate in the passive resistance movement, and therefore serves to contradict assessments of Gandhi's lack of participation with non-Indians. However, this involvement is even more significant when we realize that it was a unique political occurrence in their own history in South Africa. It was the first time that the Chinese community was directly active in political agitation, yet it was not the first or only time that they were subjected to discriminatory legislation. The question therefore arises whether Gandhi was the instrumental catalyst in Chinese participation in passive resistance? Was it merely a coincidental and mutually beneficial alliance forged for purely pragmatic reasons as has been contended, or can a degree of leadership and influence among the South African Chinese be claimed for the Mahatma? Moreover, how did Gandhi view other Asians and what was the nature of his interaction with the Chinese community, notwithstanding his being stereotyped a “segregationist”, disinclined to seek allies because they were apparently unnecessary? ${ }^{35}$

\section{Sugar and Gold}

Before considering the part played by the Chinese in the genesis of passive resistance in South Africa and Gandhi's role in its evolution, a brief comparative overview of the Indian and Chinese communities in South Africa will serve to illustrate their common experience of oppression under discriminatory legislation and therefore explain the feasibility of a political alliance, given the common ground. At the turn of the eighteenth century, Chinese and Indian

\footnotetext{
${ }^{30}$ Karen Harris, “Gandhi, the Chinese and Passive Resistance” in Gandhi and South Africa: Principles and Politics, ed. Judith Brown and Martin Prozesky (Pietrmaritzburg: University of Natal Press,1996), 69-95; My thanks are due to Natal University Press for granting permission to rework and publish this chapter.

${ }^{31}$ Karen Harris, “A History of the Chinese in South Africa to 1912”, D Litt et Phil, Unpublished thesis, Unisa, 1998.

${ }^{32}$ Melanie Yap and Dianne Man, Colour, Confusion and Concessions (Hong Kong: Hong Kong University Press, 1996), chapter 6.

${ }^{33}$ Yap and Man, Colour, Confusion and Concessions, 137.

${ }^{34}$ Yap and Mann, Colour, Confusion and Concessions, 137.

${ }^{35}$ Hunt, "Gandhi and the Black People", 20-1.
} 
immigrants were both part of the social landscape at the Cape. They were mainly traders, servants, ex-convicts or slaves. ${ }^{36}$ Their numbers were extremely small and hardly any growth was recorded until the mid-nineteenth century when the sugar, diamond and gold industries emerged. Free Chinese and so-called passenger Indians arrived to serve these developing areas, particularly the gold-mines in the Transvaal, and to establish small trade and service businesses. ${ }^{37}$ The volume of this late nineteenth century immigration was augmented by disasters experienced in both countries of origin, where droughts, famine, floods, overpopulation and internal strife prevailed. ${ }^{38}$ As a result, there were over a thousand Chinese living in the Transvaal by the turn of the twentieth century, ${ }^{39}$ and although the Indian population was estimated at between ten and fifteen thousand at the outbreak of the South African War, ${ }^{40}$ Swan argues that the non-dependent adult male Indian population was also around a thousand. ${ }^{41}$ In the absence of accessible information, it has to be assumed that the Chinese occupied the same privileged stratum of Transvaal society as the independent Indians $^{42}$ - a position they could perhaps have retained if it had not been for the importation of indentured labour.

In 1860 the first Indian contract labourers were introduced, to work on the sugar plantations of Natal, ${ }^{43}$ and in 1904 the Chinese indentured system became an integral part of gold-mining in the Transvaal. ${ }^{44}$ It is significant that in the deliberations surrounding the introduction of this kind of labour both Indians and Chinese were considered for the scheme. ${ }^{45}$ Of more importance, however, was the influence that the Natal experience of indentured labour had on the Transvaal system which, on white insistence, stipulated that the Chinese were not to enter the Transvaal on the same conditions as Indians had entered Natal. ${ }^{46}$ Consequently, there was a stark contrast between the terms of the Natal legislation and those of the subsequent Transvaal ordinance. ${ }^{47}$ According to Law 14 of 1859, Indian labourers were to serve a five-

\footnotetext{
${ }^{36}$ Richard Elphick and Herman Giliomee, The Shaping of South African Society (Cape Town: Maskew Miller Longman, 1990), 116, 184, 209, 213, 217-24; Karen Harris, The Chinese 'South Africans': An Interstitial Community in The Chinese Diaspora, Selected Essays, vol. 2 ed. Ling-chi Wang and Gungwu Wang (Singapore: Times Academic Press, 1998), 276.

37 Surendra Bhana and Joy Brain, Setting Down Roots: Indian Immigrants in South Africa, 1860-1911 (Johannesburg: Wits University Press, 1990), 34-5, 96: Karen Harris, The Chinese in South Africa: A Preliminary Overview Kleio, xxvi, 1994, 16-7.

${ }^{38}$ Ta Chen, Chinese Migrations with Special Reference to Labour Conditions (Washington: Washington Government Printing Office, 1923), 5-11; Bhana and Brain, Setting Down Roots, 35.

${ }^{39}$ PRO (Public Record Office): CO 291/75 no. 10687, 24 March 1904: Colonial Secretary Lyttelton in Parliament; Indian Opinion, 31 August 1907; Huang, Chinese Abroad, 50.

${ }^{40}$ B. Pachai, The History of the Indian Opinion, 1903-1914, Archives Year Book for South African History (Pretoria: Government Printers, 1963), 22; Bhana and Brain, Setting Down Roots, 78; Ly-Tio-Fane Pineo, Chinese Diaspora, 218.

${ }^{41}$ Swan, Gandhi, 1-2.

42 Indian Opinion, 31 August, 26 October 1907; Bhana and Brain, Setting Down Roots, 96-7; Swan, Gandhi, 2.

${ }^{43}$ Surendra Bhana, Indentured Indian Emigrants to Natal, 1860-1902: A Study Based on Ships' Lists (New Delhi: Promilla and Co, 1991), 19; Bhana and Brain, Setting Down Roots, 29.

${ }^{44}$ Peter Richardson, Chinese Mine Labour in the Transvaal (London: Macmillan Press, 1982), 166.

45 PRO: CO 291/65 no. 15307/03, Correspondence re labour from India for the Mines; Indian Opinion, 24

March 1906; Natal Mercury, 9 November 1855; W. Gait, The Rand Crisis', Natal University Law Review 1, 4, 1975, 191; Richardson, Chinese Mine Labour, 32.

${ }^{46}$ Persia Campbell, Chinese Coolie Emigration to Countries within the British Empire (New York: Routledge, 1923), 171-2.

${ }^{47}$ For a detailed analysis of this see Karen Harris, Sugar and Gold: Indentured Indian and Chinese Labour in
} 
year term of indenture, at the end of which they could either be re-indentured or live as free people in the country. After ten years' residence in Natal they also had the option, until 1891, of taking a free return passage to India or a grant of land equal in value to a sea passage. ${ }^{48}$ The Labour Importation Ordinance of 1904, on the other hand, stipulated that all Chinese labourers had to enter a contract of service not exceeding three years, with the right of renewal for a similar period, after which they were to be returned to their country of origin. ${ }^{49}$ Therefore, apart from the other severely restrictive regulations entrenched in the latter legislation, the indentured Chinese represented a temporary expedient and could never become ex-indentured as the Indian could. In terms of political activity this meant that while the Indian merchant class and Gandhi could choose to distance themselves from their exindentured compatriots, the Chinese did not have that option. Furthermore, during the public furor which preceded the introduction of Chinese labour, the Chinese community in the Transvaal made it quite clear that it was "neither interested nor concerned with the introduction or otherwise of Chinese labour for the mines". ${ }^{0}$ Such sentiments were remarkably like those of Gandhi towards both Indian and Chinese indentured workers. ${ }^{51}$

The large-scale influx of these indentured labourers into South Africa had a profound impact on the position of those who had already settled, and on future immigrants of the Asian communities. The fear and animosity felt by many whites towards the indentured and exindentured Indians in Natal was extended to all Asian communities. ${ }^{52}$ Moreover, the gradual increase in the Asian population during the last quarter of the nineteenth century, and in particular of the Indian trading class in the Transvaal, resulted in the passing of a deluge of legislation to curb and control them. ${ }^{53}$

The first ordinance to focus specifically on Indian merchants was passed in 1885 in the Boer Republic of the Orange Free State. It required the registration of Indian communities in their magisterial districts, but as there were fewer than a dozen Indians and hardly any Chinese, the law was of little consequence. ${ }^{54}$ However, the subsequent South African Republic legislation had far wider implications. Law 3 of 1885, and its amendment, denied the "native races of Asia" the right to citizenship and ownership of fixed property, except in "streets, wards and locations" which the government assigned to them. ${ }^{55}$ It also called for their registration and insisted that they carry a pass with a stamp to the value of $£ 25 .{ }^{56}$ The Chinese were included in both these laws and were subjected to the same legislation as Indians, regardless of whether or not they had been directly implicated in the reason for its enactment. In fact, much

\footnotetext{
South Africa, Journal of Social Sciences, Special volume 11, 2010, 147-158.

${ }^{48}$ Leonard Thompson, Indian Immigration into Natal, 1860-1872, Archives Year Book for South African

History (Pretoria: Government Printers, 1952), 14.

${ }^{49}$ Campbell, Chinese Emigration, 176-7; Richardson, Chinese Mine Labour, 166.

${ }^{50}$ PRO: CO 291/67 no. 20153/1903, Chinese grievances, 25 May 1903.

51 Swan, Gandhi, xvi, 60, 113-14.

${ }^{52}$ Harris, Chinese in South Africa, 13; Pachai, History of Indian Opinion, 22.

${ }^{53}$ Edna Bradlow, "Immigration into the Union 1910-1948: Policies and Attitudes” (Ph.D. diss., University of Cape Town, 1978), 12; Pachai, Indian Question, 13-14; Bhana and Brain, Setting Down Roots, 78.

${ }^{54}$ Swan, Gandhi, 38; Harris, Chinese South Africans, 18-19.

55 Statute Laws of the Transvaal, 1, Law no.3, 1 June 1885, 135.

${ }^{56}$ Volksraad Resolution, Artikel 1419, 12 August 1886.
} 
of the future legislation which was aimed at Indians, probably because of their far greater numbers, was also applicable to the smaller Chinese community. ${ }^{57}$ It was only after Union in 1910 that "the Asian question" became "the Indian question" and acts of Parliament referred to Indians in particular rather than to Asians in general. ${ }^{58}$

Although the Indians and Chinese were therefore subjected to similar legislation and treated in a similar manner, it does not follow that they also reacted as a united force. The 1885 Transvaal legislation became a case in point, and was also significant in terms of what Swan refers to as "pre-Gandhian politics". ${ }^{59}$ During the draft phase of Law 3 in 1884, the Indian merchants petitioned the South African Republic Volksraad (State Assembly) not to introduce the discriminatory legislation as they were "men of substantial standing... engaged in flourishing businesses". ${ }^{60}$ They also made a point of forcing a class division between themselves and the "labouring class of Indians and the Chinese". ${ }^{61}$ Despite the paucity of archival material on Chinese activities, there is some evidence of their response to the 1885 legislation. Once the law had begun to be more seriously enforced, a memorandum was sent to the Volksraad in 1898 on behalf of 283 Chinese in Johannesburg, requesting that they are not segregated as a group and placed in one location. ${ }^{62}$ This petition suggests an emergent independent political consciousness on the part of the Chinese in this pre-Gandhian period. It also appears that the Chinese did not wish to be forced into locations with other Asians. Their petition also contained an objection to being removed from areas where they had established viable trading enterprises. ${ }^{63}$ It revealed an economic exclusivity similar to that of the Indian merchant class, a type of elitism which was to characterize both their separate political activities, and much of Gandhi’s initial outlook, for the next half-decade or so.

However, apart from the Indian economic claim to superiority, Indians also demanded certain rights as British subjects, based on the terms of the Proclamation of 1858 made by Queen Victoria at the commencement of British Crown rule in India. ${ }^{64}$ This declaration provided Indians with potential political leverage, since the British government had pledged itself to safeguarding the interests of the "natives of [their] Indian territories by the same obligation of duty which binds [them] to all [their] subjects". ${ }^{65}$ This was an important part of the strategy Gandhi was to employ, coupled with his emphasis on what J.H. Stone calls the "common Indo-Aryan origins of the English and Indians", which was a cultural mark of the "naturally superior status of the community" he represented. ${ }^{66}$ The majority of the Chinese had no such

\footnotetext{
${ }^{57}$ Huang, The Legal Status of the Chinese Abroad, 275.

${ }^{58}$ K. Kirkwood, The Group Areas Act (South African Institute of Race Relations, n.d.), p. 1; Huang, The Legal

Status of the Chinese Abroad, 52-3.

${ }^{59}$ Swan, Gandhi, 38.

${ }^{60}$ Pachai, Indian Question, 13.

${ }^{61}$ Pachai, Indian Question; Swan, Gandhi, 106.

${ }^{62}$ Notuten van der Eersten Volksraad der ZAR, 1898, Art. 1599, 1056.

63 Both interpretations were indicative of future Chinese objections to the 1950 Group Areas Act. See Karen Harris, “Accepting the Group but not the Area: The South African Chinese and the Group Areas Act”, South African Historical Journal 40, 1999, 179-201.

${ }^{64}$ Judith Brown, Gandhi: Prisoner of Hope (New Haven: Yale University Press, 1991), 44; Pachai, Indian Question, 5.

${ }^{65}$ Stone II, Debate: M.K. Gandhi, 727.

${ }^{66}$ Stone II, Debate: M.K. Gandhi, 726-7.
} 
"rights", with the exception of those who came from Hong Kong and Mauritius and could therefore claim to be British subjects by birth. ${ }^{67}$ On the subject of British/Indian equality and superiority, the Chinese kept themselves aloof, since any acknowledgement from them would simply have reinforced British imperial chauvinism, and denied their own sense of cultural superiority which they were to repeatedly refer to in their petitions to the authorities. Ironically, it was apparently not until a treaty concluded in 1858 that the Chinese actually agreed to relinquish the term "barbarians" when referring to Westerners in official correspondence. ${ }^{68}$

From the outset, South African Indian politics involved an interplay of three continents Britain, India and Africa - a dimension which would feature prominently in the South African Gandhian period. In 1903 the South African Chinese officially gained a similar status. With the coming of indentured Chinese labour, a Chinese Consulate-General was established in Johannesburg under the provisions of the protection granted to contracted emigrants. ${ }^{69}$ The Chinese Emperor ensured that under the agreement with the British government the Consul's powers were extended to include all the Chinese in South Africa. As a result, appeals and petitions were often channeled via the local Consul to China and also to the Chinese diplomatic representatives in Britain. ${ }^{70}$ Therefore, although the British were not as constitutionally committed to the Chinese in South Africa as they were to the Indians, the combined impact of the numerous Anglo-Chinese treaties, including the peace, friendship, commerce and navigation treaty of 1858, the most-favoured-nation concessions, the establishment of the resident Chinese minister in London in $1877^{71}$ and the Britishsanctioned Transvaal Chinese mine labour system did call for a certain degree of involvement. As a result, the Chinese made demands not as British subjects, but as members of an Empire that had treaty terms of equality with England. On these grounds, therefore, they objected to being classified with "Arabs, coolies and other Asiatics . . . that [were] not a ruling race". ${ }^{72}$

By 1900 there was thus an indication that the Chinese and Indian communities in the Transvaal were not apolitical, nor were they entirely dissimilar in status. Their resistance to the same discriminatory legislation included similar tactics, such as letters to the press, petitions to both local administrations and overseas British representatives, delegations to government, and court cases. ${ }^{73}$ There is, however, no indication of any formally organised, combined political structure or cooperation for the early period. There is some mention in the records of Indian petitioners referring to themselves as Committee members, ${ }^{74}$ and there are indications that the Transvaal Chinese had formed a clandestine organisation as early as

\footnotetext{
${ }^{67}$ PRO CO 291/67 no. 20153/1903, Chinese grievances, 25 May 1903.

${ }^{68}$ Milton Meyer, China: An Introduction (New York: Littlefield Adams, 1978), 168, 173.

${ }^{69}$ Richardson, Chinese Mine Labour, 37.

${ }^{70}$ SAB: (Central Archives Depot, Pretoria), BEP 575 G18/54 Raadpleging en koordinasie met ander instansies: Sjinese organisasies, 7 Desember 1963.

${ }^{71}$ Meyer, China, 170-5.

${ }^{72}$ PRO: CO 291/67 no. 20153/1903, Chinese grievances, Petition from Chinese Community, December 1902.

${ }^{73}$ Indian Opinion, 14 January 1904, 7 April 1906; Swan, Gandhi, 85, 105.

${ }^{74}$ Swan, Gandhi, 83, 124 note14.
} 
$1880,{ }^{75}$ and a more open association or club by 1898 , if not earlier in $1893 .^{76}$ It was only after the South African War (1899-1902), however, that any form of permanent political organisation was established. In 1903, Gandhi founded the Transvaal British Indian Association (BIA) ${ }^{77}$ Coincidentally, the Chinese Association (CA) came into existence the same year, either as a resuscitated pre-War institution or as a new creation. ${ }^{78}$ Both organisations were informally structured; they lacked written constitutions and were voluntary unions for joint consultation within their respective communities and for the protection of their interests. ${ }^{79}$ This was despite the fact that the Indians, at least, had a forerunner and sister organisation, the Natal Indian Congress, with well-defined leadership, formal membership and other institutional mechanisms, which they could have emulated. Moreover, neither of the bodies was particularly active in the first few years after inception, ${ }^{80}$ even though Asian legislation in the Transvaal Colony did not improve under the post-War British administration.

\section{Separate Struggles}

After the British takeover of the Transvaal in 1902, the High Commissioner Lord Milner made it clear from the outset that he was "reluctant to embark on fresh legislation” regarding the position of the British Indians in the newly-acquired colony, apparently "in view of many difficulties". ${ }^{81}$ But circumstances proved otherwise, as more restrictive legislation was introduced. The Peace Preservation Ordinance of 1903, which granted permits to refugees returning to the Transvaal was followed by an additional voluntary re-registration requiring more detailed certificates; Law 3 of 1885 was virtually re-enacted in Government Notice No. 356 of 1903 as far as separate locations for most Asians was concerned; a separate Asiatic Department was created to administer Asian affairs; and the Receiver of Revenue was ordered not to issue new annual trading licences to Asians unless proof of pre-War trading was submitted. ${ }^{82}$ The reaction, including low-key meetings, petitions, letters and deputations by the BIA and members of the Transvaal Chinese community respectively, had little effect, either in terms of government response or of political mobilisation. This was also to be the case with Gandhi's first call to passive resistance in January $1904 .^{83}$

It was only in 1906, with the promulgation of the infamous "Black Act", that the first signs of more concerted action by the Chinese and Indians became apparent. This legislation initiated simultaneous resistance by these two relatively exclusive communities for the first time, and also marked Gandhi's first involvement in Chinese affairs. The legislation in question was introduced by the Transvaal legislature as the Draft Asiatic Law Amendment Ordinance No.

\footnotetext{
${ }^{75}$ Ly-Tio-Fane Pineo, Chinese Diaspora, 129. Unfortunately no primary reference is given.

${ }^{76}$ TAD (Transvaal Archives Depot): Witwatersrand Local Division WLD 5/129/51 1909 refers to a constitution being adopted in 1893; Indian Opinion, 31 August 1907.

${ }^{77}$ Pachai. Indian Question, 33.

78 TAD: WLD 5/129/51 1909, 2.

${ }^{79}$ Indian Opinion, 31 August 1907; Swan, Gandhi, 103-4.

${ }^{80}$ PRO: CO 291/67 no. 20153/1903, Chinese grievances, 25 May 1903; Swan, Gandhi, 105.

${ }^{81}$ Swan, Gandhi, 103, 117.

${ }^{82}$ Indian Opinion, 4 June 1903, 13 April 1907; Ly-Tio-Fane Pineo, Chinese Diaspora, 220-1, 249 note 32;

Huang, Chinese Abroad, 49; Brown, Gandhi: Prisoner of Hope, 33, 45.

${ }^{83}$ PRO: CO 291/67 no. 20153/1903, Chinese grievances. 25 May 1903; Swan, Gandhi, 105, 117.
} 
29 of 1906. It demanded the compulsory registration of all Asians over the age of eight with the Registrar of Asiatics. A new certificate of registration was to be issued which required additional information, including name, residence, age, caste, and marks of identification, as well as finger and thumb impressions. The issue of trading licences was made conditional upon the production of such a certificate and the penalty for failing to comply ranged from a fine to imprisonment and deportation. ${ }^{84}$

The implications of this Ordinance were far more restrictive than any previous legislation ${ }^{85}$ and led to a marked increase in protest by both the Chinese and the Indians. Even before the draft Ordinance was published in the Government Gazette, the leading article in Indian Opinion harshly criticised the proposed legislation. The main concern was the re-registration of the Asians yet again, which it claimed was tantamount to treating Indians as "criminals". Gandhi also regarded the legislation as the thin edge of the wedge, in that it was the first piece of discriminatory legislation from which, if it were allowed to go unchallenged, more would flow. ${ }^{86}$ The principle of differentiation between British Indians and other Asians was also emphasised. ${ }^{87}$ On this point, Gandhi ${ }^{88}$ argued that the Colonial Secretary of the Transvaal, Patrick Duncan, had "not discriminated between Asiatics and Asiatics", and therefore he wished to know whether Duncan was referring to British Indians or Chinese, or other Asians. ${ }^{89}$ More letters of protest followed. Gandhi approached local and overseas government representatives and then, within three weeks of publication of the draft Ordinance, the renowned mass meeting attended by about three thousand Indians was held in the Empire Theatre in Johannesburg. Here, the first declaration of peaceful resistance was passed, for which Gandhi took full responsibility. ${ }^{90}$ It was also decided on that occasion to send a deputation to England to request the British government to disallow the legislation. Up to this point no mention had been made of the Chinese by the British Indians or Gandhi. Nevertheless, the Chinese had also not taken the legislation lightly, and they too had resolved to send a delegation to the British government to address their grievances in South Africa. ${ }^{91}$

Contrary to the implications of certain secondary sources, the Chinese delegation to London in October 1906 had not been co-ordinated with the Indian deputation, nor was it led or initiated by Gandhi. This is borne out by press reports in Indian Opinion and The Times, as well as Gandhi's own accounts of the Indian deputation. In addition, Chinese Association [CA] leader, Leung Quinn, stressed that the CA agreed with the BIA, "but it had acted quite independently." 92 The Chinese were equally dissatisfied with the Asiatic Ordinance and the

\footnotetext{
${ }^{84}$ Transvaal Government Gazette, vol.52, July-December, Asiatic Law Amendment Ordinance, no. 29 of 1906 ; Brown, Gandhi: Prisoner of Hope, 45; Ly-Tio-Fane Pineo, Chinese Diaspora, 228; Pachai, A History of Indian Opinion, 37.

${ }^{85}$ Pachai, Indian Question, 33.

${ }^{86}$ Swan, Gandhi, 119.

${ }^{87}$ Indian Opinion, 11 August 1906.

88 The Collected Works of Mahatma Gandhi (Ahmedabad: The Publications Division, Ministry of Information and Broadcasting, 1961) [hereafter cited as CWMG], vol 5, 389-92.

${ }^{89}$ Indian Opinion, 11 August 1906.

${ }^{90}$ CWMG, vol.5, 443; Pachai, Indian Question, 33; Swan, Gandhi, 119.

91 The Times, 1 December 1906; Indian Opinion, 6 October 1906.

${ }^{92}$ Indian Opinion, 12 October 1907.
} 
general treatment they had received in the Transvaal. As a result, the CA deputed a Cantonese member of the Association to go to England and present their grievances to the British government. Yuk Lin Lew, the Chinese Consul-General in Johannesburg accompanied him. ${ }^{93}$ The fact that the Chinese and Indian deputations left for England on the same steamer, the Armadale Castle, is considered a "curious coincidence" 94 and rightly so, since even Gandhi's comments indicate an initial unawareness of Chinese protest. In his first account of the Indian delegation's voyage, Gandhi singled out "three well-known men", but did not include either the Chinese Consul General or the representative of the CA. ${ }^{95}$ In his next report he recorded that the Indian delegation had "very little contact with other passengers", but mentioned the presence of the Chinese. His reference to Yuk Lin Lew was, however, limited to his dress, manner and intellect, as well as the "good English education" of his nine-year-old daughter. ${ }^{96}$

The first and only indication of any meaningful co-operation between the Chinese and Gandhi during their simultaneous but separate overseas deputations, was Gandhi's involvement in helping to draft a letter. While in London he corresponded with both members of the Chinese deputation regarding this matter and, according to Gandhi's Collected Works, helped compile the letter sent by the Chinese Ambassador in London to the British Foreign Office. ${ }^{97}$ It appears from Gandhi's letters that he did not fully endorse the petition which the Transvaal Chinese community sent to the Chinese Ambassador. Gandhi commented that the petition was not in accordance with the draft he had prepared, which was to accompany the petition to the Ambassador. He declared that "paragraph 6 of the petition [was] open to grave objection". ${ }^{98}$ Unfortunately, no details either of Gandhi's first draft or of the Chinese petition are available, ${ }^{99}$ and so the points of disagreement remain obscure. The role that Gandhi played in this brief episode neatly fits the assessment given by Swan in her conclusion: "His legal training, [and] fluency in English . . . rendered him particularly suitable for the task." "100

Aside from this brief encounter between Gandhi and the Chinese, regarding the letter and petition to the Chinese Ambassador, the two deputations continued to operate separately, and it is therefore not entirely appropriate to refer to an "alliance [being] struck" on this occasion, as Swan and others do. ${ }^{101}$ Both delegations made separate representations to the British government and wrote letters to the press to promote their respective causes. The appeals were generally similar, protesting against the same unjust treatment, humiliations and indignities suffered in the Transvaal; denouncing the Draft Asiatic Law Amendment Ordinance; and demanding that the British government recognise its obligation to rectify the

\footnotetext{
${ }^{93}$ CWMG, vol. 6, 14; Indian Opinion, 6 October 1906.

${ }^{94}$ Indian Opinion, 6 October 1906.

${ }^{95}$ CWMG, vol. 5, 467.

${ }^{96}$ CWMG, vol. 5, 468-9.

${ }^{97}$ CWMG, vol. 6, 14, 27, 56, 59-60.

${ }^{98}$ CWMG, vol. 6, 56.

${ }^{99}$ CWMG, vol. 6, 27 and on 247 in correspondence just prior to his departure back to South Africa, Gandhi wrote to a certain Mr C.H. Wang in London, about his synopsis of the Chinese grievances, and points out that "it [was] open to serious objections in one or two cases..."

100 Swan, Gandhi, 270.

${ }^{101}$ Swan, Gandhi, 137.
} 
situation. ${ }^{102}$ The Indian claim of "British subject” and Chinese "most-favoured-nation" status were also underscored in their respective representations. ${ }^{103}$ On only one occasion was reference made by the Indians to the Chinese. During the proceedings of an Indian deputation to Lord Elgin, it was stated that they hoped the grievances of the Chinese deputation had received the "utmost sympathy at the hands of the government". It was, however, added that "in so far as this [the Indian] deputation [was] concerned, the Chinese and other alien nations [did] not count"; they asked "not for the Chinese, but for [their] own fellow subjects...". 104 There was therefore no question of an "alliance" 105 even though their efforts did have the combined effect of temporarily stalling the implementation of the Asiatic Ordinance. In November 1906, Lord Elgin informed the Transvaal governor, Lord Selborne, that he rejected the legislation, and it was therefore disallowed. ${ }^{106}$

\section{Strange Bed-fellows}

This legislative victory was however to prove to be short-lived. No sooner had responsible government been granted to the Transvaal in January 1907 than the "Black Act" was reintroduced virtually unchanged. The Asiatic Law Amendment Act or Act no. 2 of 1907 was passed on 22 March to amend Law 3 of 1885 and it took effect on 1 July $1907 .{ }^{107}$ This inaugurated a new phase in the resistance movement, one in which the relationship between Gandhi, the Chinese and passive resistance was forged. Even before the Act had passed its final reading, both the Chinese and Indian communities made their objections known. At the beginning of March 1907, a deputation of Chinese merchants, shopkeepers and laundry workers approached the government on the question of the "registration of men of their class as Asiatics". ${ }^{108}$ An Indian lobby objected to finger impressions on the grounds that "for all practical purposes a thumb impression, such as is now placed upon the identification papers held by each Indian would suffice. ${ }^{109}$ Other deputations and letters to the press followed, and a mass meeting of Indians was called for 29 March 1907 at the Gaiety Theatre in Johannesburg. $^{110}$

At this meeting it was resolved to offer the government a compromise, that is, to submit to voluntary, rather than compulsory, re-registration as prescribed in the Asiatic Law Amendment Act. This would virtually fulfil the requirements of the bill, but deny the Act its ultimately offensive character. ${ }^{111}$ It was even contended by the Transvaal press that this voluntary re-registration went "further than the Ordinance" in "satisfying the fears of the European population". ${ }^{112}$ If, however, the offer was not accepted, and legislation was implemented, the response would be peaceful resistance. Although Gandhi did not propose

\footnotetext{
102 The Times, 1, 3, 4 December 1906; Indian Opinion, 17 November, 1 December 1906.

103 The Times, 1 December 1906; Indian Opinion, 17 November, 15 December 1906; CWMG, vol. 6, 114.

${ }^{104}$ CWMG, vol. 6, 115-16.

${ }^{105}$ Hunt, Gandhi and the Black People, 11.

${ }^{106}$ Indian Opinion, 8 December 1906.

${ }^{107}$ Statutes of the Transvaal, Act no. 2 of 1907.

${ }^{108}$ Indian Opinion, 3 March 1907.

${ }^{109}$ Indian Opinion 16 March 1907.

${ }^{110}$ Indian Opinion, 23, 30 March 1907.

${ }^{111}$ Indian Opinion 6 April 1907; CWMG, vol. 6, 387.

${ }^{112}$ Rand Daily Mail as quoted in Indian Opinion, 20 April 1907.
} 
the various resolutions at the meeting, it is likely that he drafted them, since the call for peaceful resistance was virtually identical to his appeal in September 1906.

Within a fortnight of these decisions, the Chinese community in the Transvaal held its own mass meeting on 14 April 1907, and decided unanimously to support the resolutions taken by the British Indian meeting. The chairman of the Transvaal CA dispatched a telegram to the Transvaal government declaring that the Chinese community endorsed the proposal of the Indians. He added that the Act was "unnecessary and wounded the feelings of the community". ${ }^{113}$ The Rand Daily Mail interpreted the Chinese decision as uniting practically the whole of the free Asian community in being as "unanimously against the Act, as, perhaps the white community [were] in favour of it". The "united front" was described as a "Gordian knot” presented to the government. ${ }^{114}$

How real or strong this "alliance" really was is difficult to assess, but what is evident from the record, is Gandhi's increased involvement with the CA as the protagonist of the resistance movement, an engagement which contradicts the claim by Hunt and others that Gandhi confined his efforts to the Indian community. ${ }^{115}$ In April 1907 the Chinese leaders met Gandhi at his office to discuss their support of satyagraha and, in May, Gandhi was invited to the first of many large Chinese meetings held at the hall of the CA to "set forth the position" and consider the next step to be taken with regard to the new "Anti-Asiatic Law". ${ }^{116}$ The Chinese audience agreed to Gandhi's proposals and took an oath in accordance with their religion (Buddhist or Confucian) to submit themselves to the "extreme penalty of the law, namely liability to imprisonment, and also to boycott the permit office”. This decision was ratified by about nine hundred Chinese who signed a document to this effect. ${ }^{117}$ In addition, Gandhi received an endorsement of his resistance strategy by the Chinese Consul-General in the Transvaal. ${ }^{118}$

The decision by the Chinese to support the Indian movement was firm and at times showed even more resolve than that of the Indians. ${ }^{119}$ Their determination then and later was often praised in the columns of Indian Opinion, ${ }^{120}$ written mainly by Gandhi. In fact, on numerous occasions, Gandhi openly admired various attributes of the Chinese, even though this was usually designed to commend their exemplary role to British Indians. In an article published in 1905, Gandhi compared the two communities living in the Transvaal, remarking particularly on their respective standards of living. He pointed out that the Chinese were not generally economically better off than the Indians, because many of them were artisans, but suggested that the Indian way of life was not qualitatively as good. He admitted that the charge of uncleanliness made against the Indians was not "totally unfounded" and added that

\footnotetext{
${ }^{113}$ Indian Opinion, 20 April 1907; CWMG, vol. 6, 420, 428.

${ }^{114}$ Rand Daily Mail as quoted in Indian Opinion, 20 April 1907.

${ }^{115}$ Hunt, Gandhi and the Black People, 8.

${ }^{116}$ Indian Opinion, 1 June 1907; CWMG, vol. 6, 427.

117 TAD: WLD 5/129/51/1909; Indian Opinion, 1 June, 31 August 1907; CWMG, vol.7, 12, 46.

${ }^{118}$ CWMG, vol. 6, 427.

${ }^{119}$ Indian Opinion, 18 May, 30 November 1907.

${ }^{120}$ Indian Opinion, 18 May, 27 April, 18 May 1907.
} 
the "rules of cleanliness could also be better, observed by them", while at the same time pointing out that the Chinese lived in "great cleanliness and [did] not stint themselves in the matter of living space". ${ }^{121}$ In the same article, Gandhi also commented favourably on the CA. He referred specifically to their hall which he described as a "strong structure . . . kept clean and tidy", and to the manner in which they organised their finances. He described the Cantonese Club as a "pucca one-storeyed building" which looked like a "good European club", and remarked that Indians would do well to imitate this achievement. ${ }^{122}$ He stated that "on seeing their way of life and comparing it with our own, [he] felt very sad". ${ }^{123}$

This admiration of the Chinese by Gandhi was also apparent in an international context. Writing about the immigrant Indian and Chinese communities in Singapore in 1905 he expressed how impressed he was with how "well off" the Chinese were, claiming that the Indians could not "hold their own against the Chinese", and concluded that it was a "shame that [the Indians] cannot keep abreast of the Chinese" ${ }^{124}$ While in London he also indicated how impressed he was by the Committee of the Chinese League which had been established by the Overseas Chinese to safeguard and promote their interests, and he urged the Indians to follow its example. ${ }^{125}$ He also spoke highly of the Chinese capacity to successfully boycott powers such as the United States and Japan when they introduced unfavourable legislation, commending this as an aspect of satyagraha. ${ }^{126}$ The reference to the successful boycotting of American merchandise refers to the 1905 Chinese reaction to disagreeable aspects of United States immigration regulations. ${ }^{127}$ This was the first modern boycott against American discriminatory treatment of the Chinese. According to sinologist, John Fairbank, it involved the old tradition of cessation of business by merchant guilds which spread to all treaty ports in China. It also involved students in mass meetings and media agitation. The result was that American trade was damaged for several months. ${ }^{128}$ Associating the Chinese with "satyagraha" was therefore closer to reality than Gandhi realized. At home he also praised the Chinese for their political unity, an attribute he encouraged among his Transvaal Indian followers. Throughout the initial phases of his passive resistance campaign, he always approved of Chinese solidarity and would continue to do so.

These relatively favourable opinions probably go some way towards explaining why Gandhi became involved in the Chinese passive resistance movement. During December 1907 especially, he appeared to be grappling with this issue, probably aware of its importance in strengthening opposition to government. In a speech at a meeting of the CA, he admitted that he had always tried "to draw a line between British subjects and non-British subjects", but that this had been rejected by the British government which persisted in classifying Indians

\footnotetext{
${ }^{121}$ Indian Opinion, 16 September 1905.

${ }^{122}$ Indian Opinion, 16 September 1905.

${ }^{123}$ Indian Opinion, 16 September 1905.

${ }^{124}$ CWMG, vol. 5, 5.

${ }^{125}$ CWMG, vol. 6, 86.

${ }^{126}$ Indian Opinion 1 July, 19 August, 30 September 1905; Indian Opinion, 26 May 1906; Indian Opinion 15 June, 31 August, 30 November 1907; CWMG, vol. 5, 329; vol 8, 212.

${ }^{127}$ Indian Opinion, 1 July 1905.

128 J. Fairbank, China: A New History (Cambridge: Harvard University Press, 1992), 245; See also PRO: CO 291/121, 23767, Chinese coolies repatriation, 5 July 1907.
} 
and other Asians together. ${ }^{129}$ He said that in spite of this, British Indians still clung to their status as British subjects. This was, he believed, where the Chinese and Indian ambitions differed, but admitted that as far as the "incidence of this wretched fight was concerned, the Chinese fight was identical". ${ }^{130}$ Rather than concede any form of alliance, he concluded that it was "adversity [that] had made the [Chinese and Indians] strange bed-fellows in the struggle”. 131

The Chinese also had a particular opinion as regards this matter. In a 1907 petition to the Chinese representative in London, a clause relating to the rights of China as an ancient civilisation and independent sovereign nation, contained the following objection:

The Transvaal legislation placed Chinese subjects on the same level as British subjects coming from India . . . [and] while it may be proper for the British government to treat its Indian subjects as it pleases, [the] Petitioner respectfully submits that subjects of the Chinese Empire should not be treated in a manner derogatory to the dignity of the Empire to which [the] . . . Petitioner [had] the honour to belong .... ${ }^{132}$

The contradiction between these two fundamental claims explains why a straightforward "alliance" between the South African Indian and Chinese communities could not be taken for granted and was never realised.

As was to be expected, the new Transvaal representative government, under Louis Botha, did not accept the voluntary registration compromise proposed by the Indians and supported by the Chinese, nor did the British government intervene on their behalf. In addition, the Immigration Restriction Bill was tabled (and received Royal sanction) in an attempt further to exclude foreigners, in particular, Asians, from the Transvaal. By this legislation, nonregistered Asians in effect became "prohibited immigrants". ${ }^{133}$ The resolution to resist the Act was thus set in motion and meetings to reaffirm commitments followed. Despite the government's extension of the deadline for registration until the end of November 1907, only 8 per cent of the Asian population complied. ${ }^{134}$

While the "two communities continued to defy the Transvaal legislation separately, they also encouraged concerted action. Gandhi and other BIA representatives often addressed Chinese meetings and, in turn, Chinese representatives were also found attending and addressing Indian meetings. ${ }^{135}$ Indians and Chinese were jointly involved in picketing the registration points to persuade their Asian compatriots not to submit to the legislation. Moreover, the role of the Chinese in passive resistance featured more prominently in the columns of Indian Opinion, and in one issue a special supplement on the Chinese leader, Leung Quinn, was also

\footnotetext{
${ }^{129}$ CWMG, vol. 7, 396-7.

${ }^{130}$ CWMG, vol. 7, 397.

${ }^{131}$ CWMG, vol. 7, 105, 397.

132 CWMG, vol. 7, 105, 397.

133 Indian Opinion, 13 July 1907; Swan, Gandhi, 142-3.

${ }^{134}$ Indian Opinion, 13 July, 9 November 1907.

${ }^{135}$ Indian Opinion, 24 August, 5, 12 October, 7 December 1907.
} 
published. $^{136}$

The readership of Indian Opinion was kept informed of the CA's activities, which reflected a determined but independent commitment to the passive resistance movement. The regulations of the Registration Act were translated and printed in pamphlet form, and a Chinese newspaper, circulated free of charge, gave weekly reports in order to inform the community of the latest developments. ${ }^{137}$ The CA also canvassed for subscriptions to a fund for the purpose of promoting Chinese passive resistance. ${ }^{138}$ In May 1908 these funds amounted to £936. ${ }^{139}$ Appeals were made to Chinese government representatives in London and Peking, the Chinese Chamber of Commerce, the Boycott Association and the Chinese Students Association in Europe, all of which considered the law completely unacceptable and therefore offered their support. ${ }^{140}$

Despite the intersection of interests between the two communities, differences nevertheless persisted. For example, in his capacity as chairman of the Transvaal CA, Quinn sent a petition to the Envoy-Extraordinary and Minister Plenipotentiary in London in October 1907. Although the petition reiterated many of the former grievances made by both communities, it also included other issues, which illustrate the continued divergence between the two communities. The longest resolution objected to the fingerprint requirements of the legislation, on the grounds that in China these were only taken from "illiterates and criminals". ${ }^{141}$ The Chinese preoccupation with this aspect represented a deviation from the more pliable attitude of the Indians who, despite initial objection, had gradually come to regard this as unimportant. Gandhi repeatedly emphasised that the question of "finger prints per se [was] not a serious matter", but rather "the compulsion and flavour of criminals behind it". ${ }^{142}$ Later on in the campaign, Gandhi chided the Chinese on this matter, writing that the more the Chinese persisted "in such childish obstinacy, the more they would lose their good name". ${ }^{143}$ One of the many reasons given by the Chinese for this objection was, however, not unlike a sentiment Gandhi himself upheld: that of an implied racial superiority. In this petition, the Chinese declared that this humiliating legal stipulation reduced them to "a level lower than that of the natives of South Africa and other coloured people”. ${ }^{144}$

Another important point, which reflects a different stance from that of the Indians, was the request by the Chinese that if the Transvaal government continued to refuse to accept the voluntary offer of re-registration, and if no substantial relief was granted, then

strong representations should be made to the British government that every Chinaman should be sent back to China subject to full compensation being paid to him for deprivation of vested interests to

\footnotetext{
${ }^{136}$ Indian Opinion, 31 August 1907.

${ }^{137}$ Indian Opinion, 13 July, 17 August 1907.

${ }^{138}$ TAD WLD 5/129/51/1909 re the Chinese Association.

139 TAD WLD 5/129 51/1909, Opposed applications Leung Quinn and Foo Kimson.

${ }^{140}$ Indian Opinion, 31 August, 9 October 1907; Yap and Man, Colour, Confusion and Concessions, 141.

${ }^{141}$ Indian Opinion, 26 October 1907.

${ }^{142}$ Indian Opinion, 14 September 1907.

${ }^{143}$ CWMG, vol. 8, 107.

${ }^{144}$ Indian Opinion, 19, 26 October 1907.
} 
trade, residence etc. ${ }^{145}$

At no time did Gandhi's or the Indian community's demands converge with those of the Chinese on these issues. Moreover, responding to an inaccurate statement in The Star, Quinn categorically stated that:

My Association has cordially agreed all through with the attitude adopted by the Transvaal British Indian Association, but it has acted from the commencement quite independently, and will continue to do so. ${ }^{146}$

Yet despite differences, the Chinese steadfastness in opposing the law and Gandhi's admiration of their tactics never wavered. The extreme nature of their commitment to united political action was evident in the way traitors were treated and how they responded. Chinese who registered - and there were no more than a few dozen - were boycotted by the community and were in consequence often forced to recant. In one such case, the "offender" publicly declared that the only penance he should endure for having taken out the "badge of slavery", was to leave the country voluntarily, while in another more tragic instance, the "offender" took his own life. This suicide victim, Quei Waei (Chow Kwai For), claimed he had been ordered by his employer to re-register, and only afterwards had he been made aware of his mistake by a compatriot. ${ }^{147}$

Apart from the widespread sympathy and attention which this suicide incident evoked, political expediency dictated that it should be exploited to maximum effect. Quinn accused the Transvaal government of the "murder of an innocent man", while Gandhi declared that an Act which

had exacted this heavy price would never be submitted to [and that they should] keep before their eyes the spirit of the dead man and remember in this struggle that virtue was its own reward. ${ }^{148}$

Meetings and memorial services followed, and at Quei Waei's funeral, Gandhi made an "eloquent appeal to all to nerve themselves for the coming struggle fittingly, declaring that the tragedy had produced a feeling of revulsion everywhere, which strengthened and consolidated the case of the Asiatics". ${ }^{149}$ Once again, he commented on the Chinese community's “unity, neatness and courage ... things [which] deserve to be emulated by [the Indians]”. 150

During November and December 1907, and again in January 1908, increasing numbers of Asians were arrested and imprisoned under the stringent clauses of the Registration Act and the Immigration Act. Among two thousand Asians charged and convicted were prominent leaders including Gandhi, Quinn and two other Chinese, John Fortoen and Martin Easton. ${ }^{151}$

\footnotetext{
145 PRO: CO 291/121, 43156, Asiatic Law Amendment Act, 18 November 1907; Indian Opinion, 26 October 1907.

${ }^{146}$ Indian Opinion, 12 October 1907.

${ }^{147}$ Indian Opinion, 16 November 1907.

${ }^{148}$ CWMG, vol.7, 397; Indian Opinion, 16 November 1907.

${ }^{149}$ CWMG, vol.7, 370; Indian Opinion, 7 December 1907.

${ }^{150}$ CWMG, vol.7, 395-6.

${ }^{151}$ Indian Opinion, 4 January 1908.
} 
Like the Indians, the Chinese appealed for the struggle to continue, pending their imprisonment or deportation, stressing the importance of continued resistance in spite of the absence of political leaders. The Chinese also thanked Gandhi on numerous occasions for the "advice given and services rendered to them in the crisis through which the Asiatic communities were passing”. ${ }^{152}$

After disobeying orders to leave the Transvaal, many of the leaders, including Gandhi and Quinn, were imprisoned. This ushered in another period of closer co-operation between Gandhi and the Chinese and revealed the importance of the former's role. Within a fortnight of their confinement, mediation with the government was again proposed in order to attempt to reach a compromise. With the help of the white community, and in particular that of the editor of the newspaper, Transvaal Leader, Albert Cartwright, Jan Smuts was persuaded to consider some kind of rapprochement. ${ }^{153}$ The substance of this compromise was the voluntary registration of Indians and Chinese under certain conditions, which would effectively make Act No. 2 of 1907 redundant. The document was drafted by Cartwright and Smuts, amended by Gandhi and then signed by Gandhi, Thambi Naidoo, a prominent Indian supporter, and Quinn in the Johannesburg gaol. ${ }^{154}$ According to the Collected Works, the initial draft of the proposed agreement, known as the "Cartwright draft", referred only to the Indian community in the introduction, and Gandhi was responsible for adding the Chinese community to the document, thereby acknowledging the role that they had played. Gandhi indicated that Quinn had “done excellent work” for the campaign. ${ }^{155}$ Gandhi was released to negotiate a provisional settlement with Smuts, and the other prisoners were released soon after. ${ }^{156}$

In the following weeks, various banquets and meetings were held by the Chinese and Indian communities to celebrate those who had assisted their cause. In his column, "Johannesburg Letter" in Indian Opinion, Gandhi wrote: “The Chinese have done something remarkable. They have surpassed us in unity, cleanliness, culture and generosity”. ${ }^{157}$ This sentiment was reiterated by the chairman of the BIA, Essop Mia, who stated at a Chinese banquet that the "Chinese have outdone the Indians. In many respects they have excelled them. It was a good thing that the Indians and Chinese presented a united front during the campaign”. 158

The initial stages of the voluntary registration proceeded smoothly, except that some members of the Chinese community objected to finger impressions on registration certificates on religious grounds. Despite Gandhi's irritability on this issue, he nevertheless intervened on their behalf so that they were only required to give their thumb impressions. ${ }^{159}$ The Chinese then registered enthusiastically, and by early March 1908 over a thousand were reported to

\footnotetext{
${ }^{152}$ Indian Opinion, 4 January 1908.

${ }^{153}$ CWMG, vol. 7, 409, vol.8, 40, 65-6, 142.

${ }^{154}$ CWMG, vol.7, 40-2, 161; Swan, Gandhi, 143.

${ }^{155}$ CWMG, vol. 8, 66.

${ }^{156}$ Indian Opinion, 1 February 1908.

${ }^{157}$ CWMG, vol. 7, 162-4.

${ }^{158}$ CWMG, vol. 8, 164.

${ }^{159}$ CWMG, vol. 8, 107, 115, 184; Indian Opinion, 22 February 1908.
} 
have made application, and the whole of the trading community had apparently received licences. Despite their reservations about the finger impressions, Chinese solidarity was once again held up to the Indian community as worthy of emulation. ${ }^{160}$

\section{Foul play}

However, just as the defeat of the 1906 Draft Asiatic Amendment Ordinance had been shortlived, so too did the success of the 1908 compromise prove transitory. The real problem arose when it became apparent that Smuts had no intention of repealing Act No. 2 of 1907. The compromise had been little more than a temporary expedient, and it placed Gandhi in an invidious position since he not only had to continue the battle with the government, but also had to convince Indians of Smuts's breach of faith, and campaign for continued resistance. In his revelations about the "foul play", Gandhi explained that Smuts had promised to repeal the Act on the successful completion of voluntary registration. He also referred to the Chinese leaders' signing of the proposal in the belief that the Act would be scrapped. ${ }^{161}$ The enforcement of the Transvaal Registration Act was seen as a breach of their compromise and Smuts was said to "have no notion of ordinary honesty" . ${ }^{162}$

Both communities resumed their former tactics of letter writing, petitions and deputations. Gandhi wrote to the Registrar of Asiatics requesting the return of his registration application and drafted a similar letter for Quinn and the other co-signatory of the proposal to forward to the Prime Minister. ${ }^{163}$ Smuts refused to accept Gandhi's demands, and so negotiations failed and a renewed phase of passive resistance ensued. ${ }^{164}$ Meetings were held to oppose the Asiatic Voluntary Registration Validation Bill which the Transvaal government was processing. On 16 August 1908 the infamous mass meeting was held at the Hamidia Mosque, Fordsburg, which was attended by over 3000 people including the Chinese leaders and their supporters. Here over 1000 registration certificates and over 500 trading licences were thrown into a large threelegged pot which was set alight and the contents publicly burned. ${ }^{165}$

The government responded by withdrawing the Validation Bill, and instead passed Act 36 of 1908, the "Asiatics Registration Amendment Act". ${ }^{166}$ Although the Act endorsed the voluntary registration of Asiatics who had failed to comply with Act 2 of 1907, it made further provisions pertaining, amongst others, to immigration, which were rejected by both the Indian and Chinese communities. ${ }^{167}$ As a result, the government commenced with a stringent application of the law. ${ }^{168}$ During the ensuing months, arrests, trials, imprisonments and deportations became the order of the day, as the communities continued to defy the law. ${ }^{169}$ However, as was the case

\footnotetext{
${ }^{160}$ Indian Opinion, 29 February, 7, 21 March 1908.

${ }^{161}$ Indian Opinion, 4 July 1908.

162 Transvaal Leader, 11 August 1908; Indian Opinion, 30 May 1908.

${ }^{163}$ CWMG, vol. 8, 264.

${ }^{164}$ Indian Opinion, 4, 11 July 1908.

165 Transvaal Leader, 17 August 1908; Yap and Man, Colour, Confusion and Concessions, 154; CWMG, vol 9, 295 claims 2500 certificates were burned .

${ }^{166}$ Statutes of the Transvaal 1908, Act 36 of 1908, Asiatics Registration Amendment Act.

${ }^{167}$ CWMG, vol 9, 294-99 sets out these various issues.

${ }^{168}$ Indian Opinion, 26 December 1908.

${ }^{169}$ Indian Opinion, 13 February, 25 September 1909; Rand Daily Mail, 10 December 1909.
} 
among the Indians, the Chinese community was not united in this renewed phase of opposition. Some felt that the government had offered them a fair compromise and they wished to return to their businesses. This led to internal disagreements. ${ }^{170}$ The first public exposure of Chinese dissension was when Quinn and the passive resisters of the CA went to court to obtain an interdict against the "non-passive resisters", known as the "party of compliance". They accused them of using funds specifically contributed to passive resistance for other purposes. ${ }^{171}$ Throughout the various stages of the campaign, the CA had used these funds to make contributions to both Chinese and Indian court cases and deputations. ${ }^{172}$ Quinn and the passive resistance section of the Chinese community broke away and formed the Chinese Reform Union (CRU) to continue the campaign, but intermittent fights continued between the two factions, including a gun battle in the street outside the Chinese quarters in Ferreirastown, Johannesburg. ${ }^{173}$

On 20 February 1909, Quinn was arrested and sentenced to three months with hard labour for failing to produce a registration certificate. ${ }^{174}$ In his absence, Chion Fan James Frank took over the leadership of the Chinese passive resisters. ${ }^{175}$ On 21 February, Quinn was joined in jail by Gandhi who was similarly arrested and convicted. In May and June 1909 respectively, Gandhi and Quinn were released and were given heroes' welcomes. ${ }^{176}$ During this time Gandhi again commented positively on the Chinese: "I am very happy that these two groups - the Chinese and the Indians - who took part in this struggle, have been brought together", ${ }^{177}$ saying of his Chinese counterpart: "Truly, Mr. Quinn is a pillar of Satyagraha... I feel proud when I come across a man of his type during my experience of our struggle". ${ }^{178}$

In the latter half of 1909, the resistance campaign acquired a new urgency, with a growing awareness that the four South African colonies were preparing for Union. The Indian and Chinese leaders feared that the Transvaal regulations might be entrenched throughout the country in a new constitution. ${ }^{179}$ In order to avert this, Gandhi led a deputation to England to request the British government to intervene on their behalf. ${ }^{180}$ While in London, passive resistance, particularly among the Chinese, escalated, and Gandhi received cablegrams from both the CA and BIA indicating that the Transvaal government arrests had increased with some 80 Chinese being arrested at one time. ${ }^{181}$ Gandhi was astounded by these developments and claimed that "the measures adopted by the Government, instead of weakening Asiatics have

\footnotetext{
${ }^{170}$ PRO: CO 291/128, 35076, Asiatic Registration Amendment Act, 7 September 1908. Yap and Man, Colour, Confusion and Concessions, 163.

${ }^{171}$ Indian Opinion, 30 January, 24 April, 24 July 1909.

${ }^{172}$ CWMG, vol. 9, 68.

173 Indian Opinion, 17, 24 April, 22 May, 25 September, 16 October 1909; TAD: WLD 5/129 51/1909, Opposed application. Leung Quinn. Yap and Man give one of the only detailed accounts of this incident, 154-7.

${ }^{174}$ Indian Opinion, 27 February, 13 March 1909.

${ }^{175}$ Indian Opinion, 13 March, 1 May 1909.

${ }^{176}$ Indian Opinion, 29 May, 5 June 1909.

${ }^{177}$ CWMG, vol 9, 236.

${ }^{178}$ CWMG, vol 9, 236.

${ }^{179}$ Ly-Tio-Fane Pineo, Chinese Diaspora, 237; Indian Opinion, 25 September 1909.

${ }^{180}$ Indian Opinion, 26 June 1909.

${ }^{181}$ PRO: CO 291/142, 31220, Treatment of Asiatics, 18 September, 1909; Indian Opinion, 18, 25 September 1909.
} 
nerved them”. ${ }^{182}$

While the British government indicated that it could not intervene on the Asians behalf, the Transvaal government stepped up its vigilance against the passive resisters. At a meeting held at the Cantonese Club in September 1909, which was attended by Chinese and Indians, resolutions were made to reaffirm their commitment to the movement. It was pointed out that since the arrests, over 100 more Chinese (probably from the "party of compliance") had joined the ranks of the passive resisters. Besides pledging support to those nobly suffering imprisonment, they also vouchsafed to preserve their self-respect and the honour of that "great Empire" to which they belonged. In addition, an appeal was made to "the members of the Chinese Students Association in Europe to espouse [their] cause, and to do their utmost to help their brethren in South Africa in this hour of need”. ${ }^{183}$

Arrests continued unabated, with Quinn, Frank and other Chinese being convicted to three months' hard labour. ${ }^{184}$ On Gandhi's return from England in December 1909, the liaison between him and the Chinese community strengthened. He addressed their meetings, joined their welcome parties for discharged prisoners and attended receptions to honour supporters of the movement. ${ }^{185}$ In March 1910, Gandhi reported that the Chinese friends are "going strong" and he understood that nearly 150 found themselves in that "haven of liberty at Diepkloof", commenting that the enthusiasm their Chinese friends were showing was "simply wonderful". ${ }^{186}$ This increased resilience of the passive resisters led to the Transvaal government's decision to remove offenders from the Colony. In April 1910, Quinn was arrested for the fourth time, and was jailed, pending deportation. ${ }^{187}$ He was reduced from being one of the wealthiest Chinese merchants in the Transvaal to the state of a pauper. He claimed he had sold all his belongings since he felt that he "could not very well retain his possessions and his self-respect in a country like this”. ${ }^{188}$ In May 1910, Quinn addressed a petition to the Chinese Ambassador in London complaining that the Transvaal legislation was "degrading, insulting and derogatory to the Chinese national honour". He requested the Ambassador to obtain a repeal of the Act so that Chinese could enter the Colony on the same terms as Europeans, and prevent what he regarded as illegal deportation. ${ }^{189}$ In addition, in a supreme court hearing, Quinn contested the right of the government to detain him pending deportation. ${ }^{190}$ The deportations continued and Quinn was included among them, leaving on the "S.S. Umfuli" for Colombo, Ceylon, on 18 May 1910. ${ }^{191}$ Some three hours prior to Quinn's departure, the Indian Opinion reported that he had had a personal interview with Smuts at the

\footnotetext{
${ }^{182}$ Indian Opinion, 18 September 1909.

${ }^{183}$ Indian Opinion, 25 September 1909.

${ }^{184}$ Indian Opinion, 15, 22 January 1910.

${ }^{185}$ Indian Opinion, 4, 11 December 1909, 29 January, 19 February 1910.

${ }^{186}$ Indian Opinion, 5 March 1910.

${ }^{187}$ Indian Opinion, 9, 16 April 1910.

${ }^{188}$ Indian Opinion, 23 April, 7 May 1910.

${ }^{189}$ Indian Opinion, 7 May 1910.

${ }^{190}$ Indian Opinion, 14 May 1910.

${ }^{191}$ Indian Opinion, 28 May 1910.
} 
General's request. ${ }^{192}$ Unfortunately there are no other records regarding the meeting to give substance to its discussions. Given the persistence of passive resistance, and the dire action that government was engaged in, Smuts was probably trying to strike a deal or offer a compromise to avert the political furore that the movement was causing, both locally and in the British parliament.

Before his departure, Quinn had made an appeal to the Supreme Court, contesting the right of the Transvaal government to detain him for over a month pending deportation. ${ }^{193}$ The case was dismissed. ${ }^{194}$ but the significance of this appeal against illegal custody lies in the difference between the approaches of Indian and Chinese passive resisters. While standing firm, the Chinese persisted in defending their legal rights; the Indians, on the other hand, believed that "as passive resisters, theirs is not to complain. Their duty [was] simply to go where they [were] forced to go, and at the earliest possible moment, to retrace their steps as soon as they became free again, and once more challenge the might of the Transvaal government”. ${ }^{195}$

Once in Ceylon, Quinn went to Rangoon to collect funds from the overseas Chinese communities. After that he attended the Kurnool Provincial Conference with Henry Polak, Secretary of the British Indian Association. Here the continued ill-treatment of Indians in South Africa was deplored and an appeal was made for further subscriptions to support their cause. ${ }^{196}$ In a letter to the Hindu press in Madras, Quinn thanked the Indian Presidency for its support and vowed to "return to the Transvaal" in order that they may take part in the struggle again, claiming they would "fight so long as there [was] breath in [their] bodies if the need arose". 197 On 30 August 1910, Quinn arrived back in South Africa, in the company of Polak. ${ }^{198}$ They were immediately detained in Durban and although Gandhi interceded on their behalf, and Polak was allowed entry, the three Chinese deportees were denied re-entry on the grounds of being "prohibited immigrants” and were returned to India. ${ }^{199}$ In Quinn's absence, Chinese passive resistance continued as both Chinese and Indians courted arrest. A reception was held at the Chinese Club to welcome and thank Polak for his support, and calls were made to continue the struggle on principle. ${ }^{200}$ This dedication was reflected in the fact that, according to Gandhi, there were apparently more Chinese in prison than Indians during 1910 and early 1911. ${ }^{201}$ Although this assessment is probably accurate, it is important to note that between 1904 and 1909 there were always more Chinese in jail than Indians, because of the indentured Chinese labourers.

In January 1911, Quinn returned from Colombo and landed in Durban, where after passing the

\footnotetext{
192 Indian Opinion, 14 January 1911.

193 TAD: ZTPD (Supreme Court of the SAR and the Supreme Court of the Transvaal Colony) 8/914, 345/1910, Leung Quinn versus Attorney General; Indian Opinion, 14 May 1910.

${ }^{194}$ Indian Opinion, 14 May 1910.

${ }^{195}$ Indian Opinion, 7 May 1910.

${ }^{196}$ Indian Opinion, 23 July, 13 August 1910.

${ }^{197}$ Indian Opinion, 13 August 1910.

${ }^{198}$ Indian Opinion, 3 September 1910.

${ }^{199}$ Indian Opinion, 15 October, 10 December 1910.

${ }^{200}$ Indian Opinion, 12 November 1910.

${ }^{201}$ Indian Opinion, 27 May 1911; CWMG, vol 11, 49.
} 
education test he was permitted entry. He was given a warm welcome by Transvaal Chinese and Indians alike. On this occasion he was featured on the front page of Indian Opinion, with a photograph entitled "Chinese courage". ${ }^{202}$ When he crossed the border into the Transvaal, however, he was again arrested and later sentenced to three months' hard labour. ${ }^{203}$ Prior to his court appearance, he visited Tolstoy Farm outside Johannesburg, and praised the leading men in India for the hospitality he received. For this, he humorously remarked, he owed thanks to Smuts for deporting him. In typical Gandhian style, when addressing the Tolstoy Farm workers, he also contended, on a more serious note, that:

after the struggle is closed, [he would] not be able to return to the complex life of commerce and that of ease and luxury of which he had more than his share. ${ }^{204}$

Not long after his release from detention, Quinn resigned as Chairman of the CA. The long imprisonments had ultimately destroyed his health. He remained a close friend of Gandhi and often visited Tolstoy Farm. ${ }^{205}$ The Transvaal Chinese community also supported the nature and work on Tolstoy Farm by making substantial donations of food and other essential materials. ${ }^{206}$ These reciprocal relations indicate that throughout the campaign there was mutual respect between the two communities in their separate but similar struggle for justice.

In 1910, the South African colonies became a Union. Not unlike the federation process in Australia, the newly-formed Union government was anxious to draft an Immigration Bill to accommodate the various inherited legislations. ${ }^{207}$ This appeared to be an earnest attempt on the part of the government and, in particular, Smuts, to settle the "Asiatic question". ${ }^{208}$ After protracted negotiations between Smuts, Gandhi and other stakeholders, the Immigrants' Restriction Bill of 1911 was drawn up. While it tried to concede some of the demands of the Asians, it also had to accommodate the salient features of the legislation of the four former colonies. ${ }^{209}$ As a result, the Bill that was finally gazetted fell short of satisfying the Asian community. The Indians immediately petitioned the government with certain amendments. Martin Easton, who had succeeded Quinn as Acting Chairman of the CA, sent a telegram endorsing the Indians' requests. In the spirit of conciliation after Union, Smuts released a large number of Indian passive resisters from prison. Claiming that there were more Chinese in jail than Indians, Gandhi intervened on their behalf, declaring he was

quite sure that General Smuts [would not] expect Indian passive resisters to desert their Chinese fellow sufferers. They naturally ask for the same protection for the Chinese passive resisters as for themselves. ${ }^{210}$

\footnotetext{
202 Indian Opinion, 7, 14, 21 January 1911.

${ }^{203}$ Indian Opinion, 21 January 1911.

${ }^{204}$ Indian Opinion, 21 January 1911.

${ }^{205}$ Ly-Tio-Fane Pineo, Chinese Diaspora, 239.

${ }^{206}$ Indian Opinion, 4 February 1911.

${ }^{207}$ Karen Harris and Jan Ryan, “Chinese Immigration to Australia in The Last Half Century of the Chinese Overseas” ed. Elizabeth Sinn (Hong Kong: Hong Kong University Press, 1998) 374-5.

${ }^{208}$ Ly-Tio-Fane Pineo, Chinese Diaspora, 238.

${ }^{209}$ Swan, Gandhi, 206-7; Ly-Tio-Fane Pineo, Chinese diaspora, 238-9.

${ }^{210}$ Indian Opinion, 27 May 1911.
} 
In 1911, a provisional settlement was reached between the Union government and the Asians on various outstanding issues. For example, some of the objections to Act 36 of 1908 were acceded to: Peace Preservation Ordinance permits were recognized, educated persons were exempted and signatures were accepted instead of finger prints. ${ }^{211}$ The Immigration Bill continued to pass through various phases of amendment before being enacted in $1913 .{ }^{212}$ As a result of these developments, the divided Chinese community set about reconstructing its businesses and resuming a low political profile. ${ }^{213}$ While there were various individual arrests in the following few years, ${ }^{214} 1912$ marked the end of the passive resistance movement for the Chinese. This was also the year in which the CA "ceased to exist" and Quinn was said to have absconded, "without handing over charges of the books and moneys of the Chinese Association in his possession." ${ }^{215}$ In Gandhi's recollection of this a decade later in Satyagraha in South Africa, he commented on this foul play, writing "that it is always difficult for followers to sustain a conflict in the absence of their leader, and the shock is all the greater when the leader has disgraced himself”. ${ }^{216}$ In a letter to the Governor General, 354 Chinese residents of the Transvaal referred to "the welcome settlement of the Asiatic question which [they were] now able to look forward to with feelings of deep and unmixed thankfulness ..." ${ }^{217}$ Thus when Gandhi called for a return to passive resistance in 1913, the Chinese did not respond because the issues objected to only concerned the Indian community. These included Union laws which did not recognize non-Christian marriages and the amended Immigrants' Restriction Bill of 1913. ${ }^{218}$

Throughout the second, third and final stages of satyagraha in South Africa, the relationship between Gandhi, passive resistance and the Chinese community was confirmed. Even though a split arose in the ranks of the Chinese towards the end of 1908, over the acceptance of yet another government compromise, the commitment of those who constituted the passive resistance party, continued undaunted until May 1911. The Chinese participation in the first phases of passive resistance was, however, meaningful in terms of Gandhian historiography. In this context, it provided a different perspective on his relations with nonIndian communities and therefore repudiated the purportedly revisionist view of Gandhi as "politically exclusive". Gandhi was not the leader of the Chinese passive resistance movement, but he did set its tone through his own philosophy of satyagraha and in many ways he did encourage and approve of their participation in the widespread political campaign against racist legislation. His constant approval of Chinese initiatives and tactics and his occasional legal assistance were also important. Although the Indians never concluded a firm alliance with their

\footnotetext{
${ }^{211}$ Indian Opinion, 18 March, 27 May 1911; Swan, Gandhi, 229-30.

212 Statutes of the Union of South Africa 1913, Act 22 of 1913, Immigrants Regulation.

${ }^{213}$ SAD: Governor General (GG) 1594, 51/926: Sentences. Petition for remission from members of Chinese Community in Johannesburg, 1911.

${ }^{214}$ SAD: CIA Commissioner of Immigration and Asiatic Affairs 34, M74, Chines traders. Registrar of Asiatics, 6 September 1913; Indian Opinion, 1, 22 April 1911.

${ }^{215}$ TAD: WLD5/259, 580/1914, Illiquid case, 1914; CWMG, vol. 29, 120.

${ }^{216}$ CWMG, vol. 29, 120-1.

${ }^{217}$ SAD: GG Governor General 1594, 51/926: Sentences. Petition for remission from members of Chinese Community in Johannesburg, 1911.

${ }^{218}$ Swan, Gandhi, 236-38; Ly-Tio-Fane Pineo, Chinese Diaspora, 237-8.
} 
fellow Asians, the Chinese, this was not because it was inexpedient, but rather because of their cultural ethnocentrism. Cultural exclusivity seemed to cut across class lines in the organization of passive resistance. The Indians and Chinese fought a similar battle, against similar laws and similar governments, ${ }^{219}$ yet their respective cultural chauvinisms kept them apart. Looked at from the perspective of Chinese passive resistance in the early 1900s, therefore, Gandhi's alleged complicity in "segregationist policies", "racialism” and "proto-apartheid" are unduly harsh. ${ }^{220}$ Rather the very nature of the legislation which singled out the Asiatics led to a united front, as they resisted a shared racist assault.

${ }^{219}$ Hunt uses a similar analogy with reference to the "Indians, Coloureds and Africans”, 20.

${ }^{220}$ Stone II, Debate: M.K. Gandhi, 726-35; Swan, Gandhi, 112-4; Power, “Gandhi in South Africa”, 445-6. 